\title{
Prisoners of a Metaphor: Secularization as a Deicidal Epidemic
}

\author{
Paolo Costa | ORCID: 0000-0002-3368-5742 \\ Senior Researcher, Centro per le Scienze Religiose, Fondazione Bruno \\ Kessler, Trento, Italy \\ pacosta@fbk.eu
}

\begin{abstract}
The article discusses the first reactions of many distinguished commentators to the impact that the CoViD-19 pandemic had on people's religious life globally. Such acrossthe-board response is investigated against the background of Peter Sloterdijk's exemplary reinterpretation of the religious vertical impulse in terms of anthropotechnics and is found defective. A more nuanced and ambivalent account of secularization is offered in the end as a viable alternative to the standard thesis of the disenchantment of the world.
\end{abstract}

\section{Keywords}

CoViD-19 epidemic - secularization - Sloterdijk - religious imaginary

\section{$1 \quad$ Prologue}

My argument begins with some pictures that disturbed the consciences of religious people during the first wave of the CoViD-19 pandemic. All these images conveyed the sense of an accomplished disenchantment of the world that makes belief in a transcendent reality superfluous. As Giorgio Agamben wrapped it up in a characteristically gloomy meditation on the pandemic entitled Sul tempo che viene (On the coming time):

Health has replaced salvation, biological life has taken the place of eternal life and the Catholic Church, which has long been accustomed 
to compromising itself to worldly demands, has more or less explicitly consented to this replacement. We should not regret the demise of this world or be nostalgic for ideas of the human and the divine that, like a face in the sand on the shores of history, are being erased by the relentless waves of time. But with equal determination we should refuse the bare life, mute and faceless, and the religion of health that governments are proposing. ${ }^{1}$

In the middle section of my article, I shall elaborate on this sweeping understanding of our secular age by focusing on Peter Sloterdijk's controversial book You Must Change Your Life. ${ }^{2}$ Here, Sloterdijk, who is a talented interpreter of the spirit of our times, employed a web of metaphors (asceticism as acrobatism; the conquest of the improbable; symbolic immune systems; ritual shells; etc.) to assess the impact of the disenchantment process on the human aspiration to go beyond "golden mediocrity" and aim higher. His view, in a nutshell, is that modern men and women are less disenchanted than idle, sated, poorly trained. My aim in the essay's concluding section, in contrast, is to show that this undiscriminating diagnosis fails to do justice to the ambivalence of modern secularity, which was not refuted even by people's erratic behavior during the first wave of the pandemic. In this sense, we could say with Wittgenstein that a powerful image still holds us captive as we think about the fate of religion in modernity. We must be careful, then, not to draw too hasty historical lections from the socially disruptive force of a devious disease such as the one that we have personally witnessed in the past year.

\section{$2 \quad$ Is Religion Dead?}

What will stay with us after the CoViD-19 pandemic is over is not only the bewilderment at a life change that no sane person could have foreseen only a few weeks before the first forced cascade lockdowns, or the collective anxiety for an indeterminate and insidious threat impending over mankind. Besides this, there are some pictures that have disturbed the consciences of those who, to evoke Max Weber, are still religiously musical despite the apparently inexorable process of the disenchantment of the world. Some of these images have already gone down in history.

1 Agamben, Sul tempo che viene.

2 See Sloterdijk, You Must Change Your Life. 
The most evocative ones are the photographs of Pope Francis shot during the extraordinary "Urbi et Orbi" blessing of 27 March 2020. Overlooking a deserted and rain-lashed Saint Peter's square, he gave voice to the feeling of disorientation afflicting Christians and non-Christians alike since the beginning of the pandemic with poignant words:

Like the disciples in the Gospel we were caught off guard by an unexpected, turbulent storm. We have realized that we are on the same boat, all of us fragile and disoriented, but at the same time important and needed, all of us called to row together, each of us in need of comforting the other. ${ }^{3}$

The second picture is dated a few days before that ominous late-March Friday and features again Pope Francis. In this case, the photograph portrays him frontally as he proceeds, surrounded by several bodyguards, in Rome, along a spectral via del Corso, with his head bowed. The destination of this remarkable ensemble of people is the church of San Marcello al Corso where the Holy Father was going to pray for the end of the pandemic.

So far, one might think that the religious imaginary troubled by the coronavirus epidemic is only that of the secular West. In fact, however, even in Saudi Arabia, religious authorities did not wait long before taking drastic measures to stem the contagion. As a result, photos of the most sacred place in Islam, the Kaaba, the cube-shaped building in the center of the great mosque in Mecca, without the tens of thousands of faithful who normally stay around it, have begun to circulate in the Western media since the beginning of March $202 \mathrm{O}$.

But perhaps the image that, more than any other picture, seemed to support the claim of those who think that during the CoViD-19 epidemic "pietas itself died out" is the sadly famous photograph of the column of military trucks, parked in Borgo Palazzo street, in the city of Bergamo, Italy, where the epidemic hit the hardest. Given the saturated condition of the city mortuary and crematorium, the special vehicles were rallied to transport 486 coffins of coronavirus victims to other Italian provinces.

In this case, the imagination of believers and non-believers was stirred by an event that is religious only in a broad sense. For the cultural ghost summoned by the anomalous funeral procession is the collapse of those social practices that in ordinary conditions function as a wall separating the artificial realm of civilization from what modern political constructivism has pictured since

3 Pope Francis, Urbi et orbi Blessing. 
Hobbes as a "state of nature:" a place only suitable for wolves, where dignity, values, morals, memory, meaning, respect, are by definition excluded.

It must have been a mental association of this kind that urged a subtle philosopher like Giorgio Agamben to harshly reproach the Catholic Church for abdicating its role as a barrier to universal profanation during the epidemic.

Because I have declared the responsibilities of each of us - he wrote in a short article entitled $A$ Question - I cannot fail to mention the even more serious responsibility of those who had the duty to keep watch over human dignity. The Church above all, which, in making itself the handmaid of science, that has now become the true religion of our time, has radically repudiated its most essential principles. The Church, under a Pope who calls himself Francis, has forgotten that Francis embraced lepers. It has forgotten that one of the works of mercy is that of visiting the sick. It has forgotten that the martyrs teach that we must be prepared to sacrifice our life rather than our faith and that renouncing our neighbor means renouncing faith. ${ }^{4}$

The theoretical background of this stern talking, which could sound insensitive and hard-hearted considering the many priests who lost their lives in Northern Italy during the peak of the CoViD-19 pandemic, is to be sought in a previous meditation by the author of Homo Sacer that was published on the same day of the 2020 "Urbi et Orbi" blessing. Here one of the cornerstones of Agamben's criticism of modernity makes its critical appearance: the concept of a bare life.

Another thing to think about, [he proclaims at the end of a 5 oo word monologue called Reflections on the Plague] is the obvious collapse of any conviction, or common faith. One could say that men no longer believe in anything at all - except for bare biological existence, which must be saved at any cost. But proceeding from the fear of losing one's life can only result in tyranny, the monstrous Leviathan with his drawn sword. ${ }^{5}$

During the health emergency, Agamben chose for himself with ill-disguised pleasure the role of devil's advocate in the global conversation flourishing around the health emergency. However, it is not only he who ended up embracing the doubt that the main victim of CoViD-19 was less the infected people than the belief in life-transcending goods, i.e. that fragile but priceless

4 Agamben, A Question, chap. 8.

5 See Agamben, Reflections on the Plague, chap. 5. 
asset which the sick people, their loved ones and more generally modern men and women tend to underestimate at their own risk and danger.

By widening the circle of dissenters, I do not have in mind here primarily the political leaders who suddenly started to thunder against the closure of the churches for blatant electoral opportunism. I am thinking, rather, of those thinkers who, while striving to do justice to the fractured and fragilized modern moral horizons, have nevertheless espoused Agamben's merciless diagnosis. An example for all. In an article entitled Religion behind Closed Doors, Italo Testa, a well-read Italian philosopher, expressed doubts similar to those articulated by Agamben, taking his cue as well from Bergoglio's solitary walk in via del Corso.

The image of Pope Francis [so begins his account] walking along the deserted streets of the Eternal City, surrounded by a police escort kept at a safe distance, while it recalls ex negativo the frames of Habemus papam $[\ldots]$ is perhaps the living symbol of that eclipse of religion which, among other things, seems to be confronting us these days. ${ }^{6}$

The term "eclipse" is deployed here purposefully. Testa, in fact, is no less severe than Agamben in registering the "voluntary abdication," the "silence," the "liquefaction," "desertion," "retreat," "capitulation," not only of the Catholic Church, which voluntarily gave up the administration of the sacraments out of respect for public health, but of all organized religions, left on the margins even in handling the symbolic dimension of the crisis. Thus, while more or less everyone took it for granted that shopping malls should remain open for the secular rite of weekly shopping (now suffused with a sacrificial aura due to the impending risk of contagion), baptisms, weddings, communions, confirmations, consecrated holidays, as well as the Sunday Eucharist and funerals, were immediately ousted from public life, or at least relegated to the shadows, almost without protest. ${ }^{7}$

But is this really the case? Can we be satisfied with such a ruthless diagnosis or are we too unwitting prisoners of one of those powerful pictures invoked by Ludwig Wittgenstein in a famous paragraph (115) of his Philosophical

6 Testa, La religione a porte chiuse.

7 Testa, La religione a porte chiuse. 
Investigations? In that short remark, the Austrian-British philosopher suggested that entire systems of thought, which may seem impeccable from a logical point of view, can actually be held captive by a misleading imaginary that is lurking and reproducing itself in the folds of their vocabulary. ${ }^{8}$

Something similar can be said to have happened, from the eighteenth century on, with the endeavors to grasp the fate of belief in the modern world. What is commonly called the "standard theory" of secularization could be pictured as the attempt to make sense of an essentially Western modern transition. ${ }^{9}$ The change that had to be explained concerned "religion" and, more specifically, Christianity. The macroscopic phenomenon was the seemingly inexorable displacement of religious belief and practice from the center of human life. Something of import that was there was no longer and secularization is the idée-force that was meant to capture such historical fact.

It was, moreover, conveyed by a rather simple master story. The most popular (and crude) versions of it claimed that once upon a time there was something (religion) that acted as a progress stopper, but when human kind eventually got rid of it, humanity began its endless journey towards its "magnificent and progressive destiny." Once upon a time, there was religious faith that prevented scientific method and rationality to be established with all their enlightening power, but when faith was overcome by modern science, human progress began to yield its cherished fruits. And so forth.

The standard theory of secularization, therefore, is better seen as a modern foundational myth. Here, though, the word "myth" is given a neutral, nonderogatory meaning, by which is intended the grand narrative whereby people responded to the astonishment produced by what to many looked like a rapid displacement of Christianity from the center of European life after the Thirty Years' War. This myth was a source both of a powerful imaginary and of a "doxa" - a common-sense view - that took religion to be a human phenomenon that is placed both in the origin and in a realm which is detached from the concreteness of people's mundane life. "Secularization" felt like a word appropriate for capturing this imagined fact, since it suggests the idea of a process leading from there (the origin) to here (the present time, which we think we are well-acquainted with) and from what is up above/abstract (the eschaton) to what is down to earth/concrete (saeculum).

8 See Wittgenstein, Philosophical Investigations, p. 48e: "A picture held us captive. And we could not get outside it, for it lay in our language and language seemed to repeat it to us inexorably" [Ein Bild hielt uns gefangen. Und heraus konnten wir nicht, denn es lag in unserer Sprache, und sie schien es uns nur unerbittlich zu wiederholen].

9 See Joas, Faith as an Option, Introduction. 
Once agreed on this, are we to conclude, then, that the imagery enveloping the meditations on the alleged eclipse of religion at the time of the CoViD-19 pandemic is not that different from the stance which dominated the golden age of the theory of secularization? Are we still spellbound by the idea-force of the zero-sum game between belief and unbelief, the water and the oil of human history that never mix and indeed continuously compete to stratify themselves in the most advantageous way? And, along with it, is not precisely the image of a religion perpetually under scrutiny, compelled to prove that it lives up to both the present time and its past glories, the unthought that has colonized the educated public sphere?

In what follows, I would like to elaborate on this aspect of the corona crisis by focusing on a rewarding but problematic book, You Must Change Your Life, by possibly the most talented image-maker in the current philosophical scene: the German philosopher Peter Sloterdijk. In a recently published collection of essays, he even resorted to the metaphor of a "deicidal epidemic" (theozidale Epidemie) to pin down the impact of the disenchantment process on human religious imagination. ${ }^{10}$ And, still, if one should rely on how the book has been greeted by the majority of professional readers, one might conclude, with good reason, that You Must Change Your Life belongs to a group of works that exert a special pull on religiously musical people. ${ }^{11}$

The author himself offered a self-description along these lines in a conversation with Cardinal Walter Kasper:

I know the musical quality of the Christian message and - to evoke Max Weber once more - I would consider myself religiously musical, which is a dangerous statement, incidentally, because it associates the religious relation with a gift, a talent. [...] I feel closest to the Protestant philosopher of religion William James here. What I have found very convincing in his position is the idea that the interest in religion itself may already be religion. [...] As to religion, only one thing is important, namely the openness, the readiness to experience. If one can look at a rose properly, said our [Lutheran] catechist, then something more substantial may be understood than if one is verbally committed to Christ. I have always felt

10 See Sloterdijk, After God, p. 5 (translation modified).

11 See, for example, Kirsch, Against Cynicism; Mathewes, Can You Change Your Life?, pp. 34-47; Mendieta, Review; Ansell-Pearson, Philosophy of the Acrobat. 
at home in this danger zone. And, of course, things like that don't get better with age. ${ }^{12}$

Building on these remarks, one may actually get the impression of being faced with just another offshoot of that change of atmosphere that usually goes under the name of "return of religion." By this I mean not so much the comeback of religious actors onto the world stage - from which they never went away - as the renewed attention aroused by religion-related phenomena in the Western public discourse. Such an impression, however, is misleading. For Sloterdijk makes it clear straightaway that "a return to religion is as impossible as a return of religion - for the simple reason that no 'religion' or 'religions' exist," at least they do not exist in the way they have been traditionally conceived of by their practitioners. According to his redescription of the situation:

something is indeed returning today - but the conventional wisdom that this is religion making its reappearance is insufficient to satisfy critical inquiries. Nor is it the return of a factor that had vanished, but rather a shift of emphasis in a continuum that was never interrupted. The genuinely recurring element that would merit our full intellectual attention is more anthropological than 'religious' in its implications - it is, in a nutshell, the recognition of the immunitary constitution of human beings. ${ }^{13}$

For Sloterdijk, to cut a long story short, there is an inherent connection between the Homo immunologicus and the "upward-tending animal" or, to use his terminology, the "Homo repetitivus, Homo artista, the human in training."14 It all starts with the "organismic early forms of a feeling for transcendence" that

12 See Ross, Religion ist nie cool, p. 6 et seq. "Ich kenne die Klangfarben der christlichen Botschaft und würde mich - wenn wir schon bei Max Weber sind - im religiösen Sinne für musikalisch halten, was übrigens ein gefährlicher Satz ist, weil er das religiöse Verhältnis auf eine Begabung abbildet. [...] Ich fühle mich dem Standpunkt des protestantischen Religionsphilosophen William James am nächsten. Bei ihm habe ich die für mich sehr überzeugende Annahme gefunden, dass schon das Interesse für Religion die Religion selbst sein kann. [...] An der Religion ist eigentlich nur eines wichtig, nämlich die Offenheit, die Erfahrungsbereitschaft. Wenn einer eine Rose richtig anschauen kann, sagte unser Religionslehrer, dann hat er möglicherweise vom Wesentlichen mehr verstanden, als wenn er sich verbal zu Christus bekennt. In dieser Gefahrenzone bin ich seit jeher zu Hause, und so etwas wird naturgemäß mit den Jahren nicht besser." For an argument along the same line, see Sloterdijk, You Must Change Your Life, p. 23 et seq.

13 Sloterdijk, You Must Change Your Life, p. 3.

14 Sloterdijk, You Must Change Your Life, p. 10. 
constitute the "stuff from which the forms of anthropotechnics are made."15 By "anthropotechnics" he means "the methods of mental and physical practicing by which humans from the most diverse cultures have attempted to optimize their cosmic and immunological status in the face of vague risks of living and acute certainties of death."16 His book, accordingly, adventurously reconstructs the historical rise and today's steady decline of the "vertical tension that is inseparable from human existence."17 This impulse, in turn, has been the major source of the mental and physical exercises ("ethical acrobatism") devised along the centuries to transform outstanding individuals and render them fit and qualified for such self-transcending efforts. But since the vertical tension is constitutive of any demanding practice, Sloterdijk's provocative reinterpretation of religious asceticism as anthropotechnics ends up looking like a genealogical exercise in both debunking of religion and retrieval of a transhistorical human disposition.

In this sense, he can be legitimately counted among the supporters of the master narrative of secularization as the story of an improving "subtraction." Modernity, in his view, is an axial Counter-revolution, which closed the gap between earth and sky opened up by the higher religions and ethics in the first millennium все. This U-turn has marked the end of the "hochkulturelle Dualismus"18 and, along with it, of the metaphysical delusions (God and soul) as well as of all the vagaries about a world behind the apparent world. Against this historical backdrop, secularization is seen both as ultimate disenchantment (in his own words: "a trend towards the de-spiritualization of asceticisms") ${ }^{19}$ and as accomplished "worldliness." It is the age, that is, when the world, monistically understood, establishes itself as the insurmountable horizon of human thought and agency. There is only one world and there is no room for a two-tiered view of reality: "The authentic philosophy of modernity is the hermeneutics of the monstrous, as theory of the one and only world."20

This does not mean, however, that Sloterdijk is wholly at peace with this state of affairs. For he senses in it the risk of a self-indulgent "reconciliation of humans and the world," ${ }^{21}$ rubricable under the label of Enlightenment abstractions. What he is gesturing towards, here, is how the modern idea of "progress" contributed to flattening people's moral goals by dissolving them in an

\footnotetext{
15 Sloterdijk, You Must Change Your Life, p. 8 (italics added).

16 Sloterdijk, You Must Change Your Life, p. 10 (italics added).

17 Sloterdijk, You Must Change Your Life, p. 124; see also p. 12.

18 See Sloterdijk, After God, p. 211 ("high-culture dualism").

19 See Sloterdijk, You Must Change Your Life, p. 61.

20 See Sloterdijk, Chances in the Monstrous, p. 215.

21 Sloterdijk, You Must Change Your Life, p. 437.
} 
anonymous process of technological innovations. ${ }^{22}$ At the end of the day, though, he is reluctant to interpret the modern vestiges of perfectionism as a mere translation into a profane form of a religious substance that would underlie the course of human history. ${ }^{23}$ For Sloterdijk, on the contrary, the transhistorical truth core encapsulated in the ascetic practices flourished in the ages of high religious voltage is better grasped through a secular vocabulary revolving around the idea of anthropotechnics. ${ }^{24}$

From time immemorial, human beings have refashioned themselves by means of training and exercise. As a result, the best among them stood out in virtue of "acrobatic" skills that few are able to display but are admired or, at least, observed with curiosity by the many. Such an ascending impulse, however, is properly grasped when it is uncoupled from any supernatural dimension and seen as an upward movement wholly internal to life. The verticality, in short, must be thought of as a self-transcendent process that generates more of itself ("more life") - a puzzling "natural anti-naturalness"25 - and, due to life goods' inherent fragility, at the same time elicits an exonerating reaction as a form of compensation. ${ }^{26}$

The modern secular stance that prevailed at the end of the day is indeed the product of a watered-down compromise between two contrasting exigencies (i.e., denial of transcendence and human enhancement) leading to "the dissolution of traditional hierarchical systems" and to what Sloterdijk pithily calls a "deverticalization of existence." ${ }^{27}$ As an alternative to this, he argues in his pars construens for a more ambitious trade-off between vertical tension and "an expansion of the concept of immunity" with the aim of making a future global civilization more sagacious and less self-defeating. ${ }^{28}$

In brief, what the "Enlightenment zealots"29 typically fail to understand is, to begin with, the general lesson drawn in a different context by Robert Bellah in his book Religion in Human Evolution: nothing is ever lost in human evolution. ${ }^{30}$ With respect to the disenchanting or even "deicidal" impact of

22 Sloterdijk, You Must Change Your Life, p. 371.

23 An echo can be heard here of the criticism addressed to the "secularization theorem" by Blumenberg, The Legitimacy of the Modern Age, part I.

24 For an analysis of the concept, see Lucci, L'animale acrobatico, pp. 78-97.

25 See Sloterdijk, You Must Change Your Life, p. 125.

26 Sloterdijk, You Must Change Your Life, pp. 117-119. Sloterdijk's non-Darwinian teleological view of evolution is reminiscent of Simmel's take on Nietzsche; see Simmel, Nietzsche and Schopenhauer.

27 Sloterdijk, You Must Change Your Life, pp. 127 and 371.

28 Sloterdijk, You Must Change Your Lif, p. 45o.

29 Sloterdijk, You Must Change Your Life, p. 37o.

30 See Bellah, Religion in Human Evolution. 
what Karl Jaspers famously called the "Axial Turn," for example, the process cannot be overturned unless in a catastrophic manner. ${ }^{31}$ The major discovery of the axial religions and philosophies, as Jaspers first showed, concerns the unbridgeable gap between life goods such as prosperity, health, fertility, handsomeness, etc. and the Good underpinning any kind of particular goodness, which is the only thing worthy of being worshipped. ${ }^{32}$ Spiritual innovations of this magnitude are indeed irreversible and function, as it were, as worshipselector in the sense encapsulated in a renowned chain of sentences marshaled by the American novelist David Foster Wallace.

Here's something else that's true. In the day-to-day trenches of adult life, there is actually no such thing as atheism. There is no such thing as not worshipping. Everybody worships. The only choice we get is what to worship. And the outstanding reason for choosing some sort of god or spiritual-type thing to worship - be it J.C. or Allah, be it Yahweh or the Wiccan mother-goddess, or the Four Noble Truths, or some infrangible set of ethical principles - is that pretty much anything else you worship will eat you alive. If you worship money and things - if they are where you tap real meaning in life - then you will never have enough. Never feel you have enough. It's the truth. Worship your own body and beauty and sexual allure and you will always feel ugly, and when time and age start showing, you will die a million deaths before they finally plant you. [...] Worship power, you will feel weak and afraid, and you will need ever more power over others to keep the fear at bay. Worship your intellect, being seen as smart - you will end up feeling stupid, a fraud, always on the verge of being found out. And so on. [...] They're the kind of worship you just gradually slip into, day after day, getting more and more selective about what you see and how you measure value without ever being fully aware that that's what you're doing. ${ }^{33}$

Put in Sloterdijk's terms, the enhanced anthropogenesis we have undergone in modern times would have been impossible without the breakthrough made possible by the access to an ideal realm through which people are put in touch with a "fold" of reality that, like a sort of evolutionary nova effect, has the effect, in the long run, of relativizing any historically contingent way of life and endlessly multiplying the possible modes of being in the world. From here arise

31 See Jaspers, The Origin and the Goal of History.

32 See Taylor, What Was the Axial Revolution?

33 See Wallace, This Is Water, pp. 97-110. 
the multifarious arrangements of activity and passivity allowing modern men and women to enjoy the most varied sorts of flourishing under the guise of "ethical self-transformation." ${ }^{4}$

Yet, understanding anthropogenesis this way is so onerous and challenging that a lingering uncertainty with regard to the best available vocabulary and conceptual armory is going to be the default epistemic condition in this domain. Coming to see such intricacy ought to recommend everyone a safe dose of humility in singling out the viable options and, especially, in discounting some of them as beyond the pale, as may happen, for instance, once religious transcendence ("the world above") is pictured as "the oldest parasite in the world," as we read in a revealing passage of You Must Change Your Life. ${ }^{35}$

A more general alarm bell can be found in the characteristic aftertaste that Sloterdijk's book leaves in its wake. By this I mean the poignant sense that the two opposing claims, (a) "religion does not exist" and (b) "religion is everywhere," are perfectly interchangeable and can both fully make sense of his long-winded argument. For, to bring back through the window what had been thrown out of the door, one has only to mean by "religion" a special attentiveness to things instead of seeing it as "a separate category of human action and experience," either a faith in the "surreal" 36 or "the most comprehensive immunitary praxis of the symbolic kind [...] against the authority of appearances."37

Sloterdijk himself depicts the theoretical work undertaken in You Must Change Your Life as a circular effort where the explication is the final outcome of an intellectual process in which the "familiar" is reiterated and highlighted with the purpose of polemically re-describing it by means of translation exercises that, albeit internal, may disclose their generalizable truth content beyond their context of discovery. ${ }^{38}$ More concretely, this means that religious practices can be re-interpreted as ways of coping with the vertical challenges inherent in human existence. These originate from the basic fact that "every individual, even the most successful, the most creative and the most generous, must, if they examine themselves in earnest, admit that they have become less than their potentiality of being would have required."39 "Anthropotechnics,"

\footnotetext{
34 See Sloterdijk, The Art of Philosophy, p. 8; see also pp. 27-34.

35 See Sloterdijk, You Must Change Your Life, p. 9.

36 Sloterdijk, You Must Change Your Life, p. 440 et seq., where he speaks of "the exuberance of surreal ascents, hungry for a world beyond."

37 Sloterdijk, You Must Change Your Life, pp. 92, 333 et seq.; see also p. 86 et seq.

38 See Sloterdijk, You Must Change Your Life, p. 15: "Repetition plus translation plus generalization results, with the correct calculation, in clarification. If there is such a thing as 'progress in religion', it can only manifest itself as increasing explicitness." 
then, is offered as the right word to designate this restless and inherently dynamic way of being-in-the-world.

Yet, if one is honest to the end, it must be conceded that the conclusion is underdetermined. For what justifies a reading of this "work on oneself" in terms of a technical, active self-creation, rather than as an expansion of receptivity and self-denial? ${ }^{40}$ Is there any other warrant besides the fallible recognition of the contingent fact of modern western Verweltlichung? And why should we be persuaded to see it as the definitive, self-interpreting result of human history?

These counterarguments are insufficiently considered in Sloterdijk's account. And his strict monism (or one-dimensionalism) seems, furthermore, at odds with his own call not to lose sight of "the treasuries of practice knowledge [which] are overflowing, despite being rarely frequented in recent times" and to inaugurate "another cycle of secessions [...] in order to lead humans out once again - if not out of the world, then at least out of dullness, dejection and obsession, but above all out of banality, which Isaac Babel termed the counter-revolution." ${ }^{41}$

Indeed, Sloterdijk could do justice to his own rich and nuanced metanarrative that, combining Nietzsche with William James, aims at reconciling "Höhe" (height) and "Vielfalt" (plurality), only if he were able to keep his view of history open. ${ }^{42}$ Such an open-ended stance, I think, might rest on firmer footing if, instead of staking everything on the slippery concept of anthropotechnics, Sloterdijk had made a greater preliminary effort to produce a weaker but more inclusive concept of religion, as Bellah, for one, did at the outset of Religion in Human Evolution. ${ }^{43}$ The more so in view of the fact that the German philosopher often assumes an essentialist concept of religion whenever it comes in handy for framing negative existential judgments ("there is no religion"), without ever being concerned about the need to explicitly define it: he simply takes it for granted. ${ }^{44}$ As a result, Sloterdijk constantly wavers between a substantive and a formal view of religion, moving back and forth between claiming that religion is "the most comprehensive immunitary praxis of the symbolic kind" 45

\footnotetext{
$40 \quad$ On this point see Mathewes, Can You Change Your Life?

41 See Sloterdijk, You Must Change Your Life, p. 440 et seq.

42 See Sloterdijk, Chancen im Ungeheuren, $\S 7$.

43 See Bellah, Religion in Human Evolution, Preface.

44 For evidence that he is aware of the problem, see Sloterdijk, The Art of Philosophy, p. 8 et seq.

45 Sloterdijk, You Must Change Your Life, p. 333.
} 
and seeing it as "a rhetorical-ritual mode and an immersion procedure that can serve any project." 46

In a sense, the strategy is ingenious, because it allows Sloterdijk to make the most of the predictable anthropocentric bias of the majority of his readers. And yet, one could object, if there is a common ground among the wide range of phenomena falling under the banner of "religion," this has less to do with a dissatisfaction with the way we humans are made by bad habits than with a substantial hesitation caused by the wistful question: "is that all there is?" And such a basic scruple can be a perfectly adequate source of that unconditional command to change one's own life for the better (the higher!), growing out of the thing of experience, like in Rilke's sonnet, the Archaic Torso of Apollo, from whose last line the book takes its title.

Why is this point so important? It is not just a matter of pedantry. What is at stake here is substantial and concerns how to balance our sense of historical continuity and discontinuity in the master narratives that are needed to understand the both dangerous and interesting times we are living in today. What is debatable in Sloterdijk's take on the issue is precisely his "grand sphero-immunological 'massive redescription' [...] of the history of human culture from the very first beginnings of human evolution all to the postmodern and now supposedly posthuman present" and the resulting emphasis on the epoch-making transition from the "symbolic strategies of immunization towards technical strategies of immunizations." ${ }^{47}$ For, if observed against the religious history of humanity, the magnitude of the modern caesura seems to result less from the technical "creation of protective, immunizing inner world or inner spaces," 48 than from changes in the access modes to that realm of ideal relations among widely shared experiential contents, over which no one can legitimately claim exclusive monopoly. Once the invisible heart of human experience, as it happens with the post-axial religions or philosophies, comes to be seen, for example, either as a higher mind or a current of unbounded love or a hidden cosmic harmony, life may take a radically different shape. In religious experience, as well as in any other domain of human existence, fear matters, of course, but is not necessarily the overriding factor. What is indeed remarkable in mankind's history is rather the extent to which the pull of larger spaces, of the "unknown," the uncanny, has constantly prevailed over the urge for shaping and inhabiting immunological "bubbles." And it is precisely this impulse to expansion experienced by the vulnerable creatures human beings

$46 \quad$ Sloterdijk, You Must Change Your Life, p. 96.

47 The quotations are taken from Lemmens, Review Essay, p. 105.

48 Lemmens, Review Essay, p. 105. 
unquestionably are, that has repeatedly aroused the curiosity and awe of the idle crowd for the few exemplary acrobats who were able to rely on it in order to considerably change their lives.

My hunch is that the cultural treasures encapsulated in these admirable efforts cannot be fully redeemed unless their indeterminate meaning is distributed more liberally between the great wisdom traditions, both secular and religious, than it is allowed by the "immuno-critical meta-meta-narrative"49 embraced by Sloterdijk in $\mathrm{Du}$ mußt dein Leben ändern. ${ }^{50}$ We need to tell a different story: a story, where, indeed, nothing is ever lost, let alone religion and metaphysics.

So, what kind of socio-theological lesson may be drawn from the recent frightening events? Is "religion" really on the way out? Are we justified in proclaiming that life, either bare or practicing, is definitely all there is?

It may be. Still, come to think of it, one of the most baffling side-effects of the new secularization debate is precisely the semantic crisis into which the concept of "religion" has gradually plunged in the last decades. ${ }^{51}$ For the more the standard claim of the inevitable decline of religious belief in modern society has been systematically downplayed, deconstructed, de-provincialised, the more difficult it has become to give an accurate definition of what, according to the nineteenth and early twentieth-century common knowledge, should have been "secularized," that is, either definitively liquidated or translated into more "mundane" forms, and therefore modernized.

The paradox is that, if one reads the débâcle of the secularization theorem as a victory of "religion" over modern atheism, one would have expected to see a well-rounded, even archaic conception of religion triumph: something akin to a "Revenge of God," to invoke the title of a popular book by Gilles Kepel. ${ }^{52}$ However, this is not what the deconstructors of the standard thesis have left in their wake. Indeed, it is not the victory of "God" or "transcendence" or "reenchantment" or "faith" or "superstition" or "spirituality" or "providence" that

\footnotetext{
49 Lemmens, Review Essay, p. 109.

50 An effort in this direction is carried out reluctantly by Sloterdijk in the second half of In the Shadow of Mount Sinai. For a convincing critical account of the book see Detloff, Review Essay.

$5^{1} \quad$ For an overview of the philosophical debate of the last fifty years, see Costa, La città post-secolare.

$5^{2}$ See Kempel, The Revenge of God.
} 
was handed us by the sophisticated efforts of the critics of the old sociological doxa, but something much more complex and ambivalent, if not elusive, both on the side of "religion" and on the side of its antonym, "secularity."

While the paradox is disconcerting - how might something that does not exist ever "secularize"? - it is, on the other hand, intelligible. The major flaw of the standard thesis, after all, consisted precisely in the crystallization, generalization and elevation of some specific historical experiences (the crisis of Latin Christianity after the Protestant schism, the birth of exclusive humanism, the evolution of the post-Westphalian nation-state, the Galilean-Baconian scientific Revolution, etc.) to laws of human evolution and progress. These hasty extrapolations had often been facilitated by essentialist, one-dimensional conceptions of religion that led those who embraced them to underestimate both the ability of religious communities to respond in an unpredictable way to the challenges of the new historical context and the redundant spiritual creativity inherent to "belief" in all its forms.

On closer inspection, the winning move of most critics of the secularization theorem was simply to ramify the relationship with our religious past. Put otherwise, they counterbalanced the linear truths that seemed to emerge from the beam of light that the supposed irreligious present projects onto the religious past by emphasizing the realm of contingency that the future opens up before the eyes of those who are called to choose and act in conditions of ordinary uncertainty. The open-endedness of the time-to-come is actually the main leverage used by the deconstructors of the secularization claim in their (successful) attempt at weakening its grip by articulating, unpacking and distributing the unsustainable burden of empirical evidence and theoretical intricacy that tacitly weighed on it.

When you think about it, since the first appearances of the word in the main European languages, the concept of "secularization" has not only been driven by experience, but has been perpetually lagging behind it. In fact, the story, repeatedly told, of the birth and diffusion of the term describes a recurring unplanned, albeit not arbitrary, migration from one semantic domain to another. ${ }^{53}$

The story begins in the 16th century when the term spontaneously emerges from the bosom of the Christian canonical tradition to designate the coming and going of goods and people between the sacred and the profane spheres of existence. This symbolic dynamism is made possible in a post-axial religion

53 On the history of the concept of secularization, see Zabel et al., Säkularisierung, Säkularisation, pp. 789-829; Bremmer, Secularization, pp. 432-437; Filoramo, Secolarizzazione, pp. $693-696$. 
such as Christianity by a two-dimensional conception of time, on which the bifurcation between the economy of salvation and the economy of survival rests. The Church itself, after all, is an institution that operates between these distinct yet intertwined plans of reality. Its primary function, in fact, is to supervise the traffic between the city of God and the earthly city, modulating the variable share of self-love and love of God among which human action oscillates as a consequence of original sin.

After the Thirty Years War and the upheaval caused, among other things, by significant theological differences in understanding the right balance between the refusal of the "century" and dedication to it, the concept of secularization re-surfaces under a new guise. Its kairotic concoction in a difficult diplomatic negotiation concerning the confiscation of a large quantity of ecclesiastical goods in the new European geopolitical context sheds light on the scope of the changing relationship between political and religious authority under way in the early modern period. With a brilliant feat of analogical thought, "to secularize" became, in that context, a synonym of "nationalize." With the benefit of hindsight, the noteworthy aspect of the incident is that, thanks to the use of a canonistic term, a historical process that could have given rise to an irreligious interpretation of the situation was instead traced back, at least in part, to the Christian worldview. Along the way, the question of the secular nature of the state or, more generally, of the functional differentiation of the political sphere from the religious one took on its typically modern form.

Finally, during the eighteenth century, following a series of profound social transformations and an understandable wave of diffidence towards the religious enthusiasm bloomed during the European Wars of Religion, a further significant semantic migration occurred. It was heralded by the European intelligentsia's growing need to give a name to the first symptoms of the decline of Christianity in Europe. The polemical comparison with the Middle Ages played, in this case, a decisive role. However, this was not just a corollary of the querelle des anciens et des moderns. In fact, the idea that the various faiths and cults are nothing but different local instances of a universal anthropological constant, which took the name of "religion," matured as well in the same period. It was David Hume, among others, who gave shape to the project of a critique of religion based on a reinterpretation of "belief" (or superstition) in the light of humanity's natural history.

Besides the antipathy of the philosophes towards the Christian faith and, even more, the popular resentment against its institutional embodiments, many in the eighteenth-century began to see the historical transition underway in Europe as a growing and irreversible "mundanization" of human mind and society. The decline of Christianity in Europe was thus increasingly 
understood less as a local and/or transitory phenomenon than as a necessary and irreversible cultural development, which concerned the human race as a whole and signaled a direction in which it was not only inevitable, but reasonable to move. In this perspective, the idea of secularization as a process within Christianity, the new model of a self-sufficient secular statehood, and the intuition of a spiritual progress confined within an exclusively worldly horizon reached a fateful synthesis.

The latest migration of the concept is taking place under our eyes today. The theory and practice of "secularization" or, more precisely, "secularity," have in fact now definitively left their European or Euro-Atlantic shell and are forced to measure themselves against a global cultural context that houses within itself local trajectories that, in some cases, are profoundly different from what made their affirmation possible in the West. ${ }^{54}$ It is in virtue of this challenge that the semantic center of gravity of the term gives the impression of being on the verge of collapsing, as if there was a terminal phase for concepts too, in which even the most illuminating categories conclude their natural evolution, gradually losing energy and resiliency.

Thus, both the concepts of "religion" and of "secularization" look weakened today. And, still, we seem to have no better alternatives at hand.

\section{$5 \quad$ Epilogue}

Going back to the starting point of my discussion, I would condense the sociotheological lesson taught by the CoViD-19 pandemic in the light of the recent secularization debate as follows. Religions have always been secular realities all the way down. And even more so are the faiths and cults that, after the rise of soteriological religions, have interpreted the invisible and enigmatic core of human existence in terms of the denial of the primacy of what Alfred Schutz famously called the prominent reality of work, fatigue, ingenious problemsolving, frustration of desires, death. ${ }^{55}$ Put more simply, embracing the "postaxial" belief that the world does not have the last word does not mean believing that the world is always wrong.

For a religion, to accept itself as (also) an immanent reality means, first of all, to deal honestly with the world for what it is and not for what one would like it to be. What we learn, for example, from Frank Snowden's informative

54 See Bilgrami, Beyond the Secular West.

55 See Schutz, On Multiple Realities, pp. 533-576. 
Epidemics and Society is therefore unsurprising. ${ }^{56}$ In the wake of the trauma of the Black Death (XIV century), the response of all European nations to bouts of epidemic plague was, without exception and regardless of cultural and religious differences, a progressive centralization of the management of sanitary emergencies under the guidance of Health Magistrates who were exclusively led by the ancient precept salus populi suprema lex esto ("the health of the people is the highest law"). Despite their having no reliable scientific explanations of the mechanisms governing the disease they were facing, the containment strategies pioneered by the northern Italian city-states of Venice, Genoa, Milan, and Florence (closure of borders, rarefaction of economic activities, quarantine, confinement of the infected in the Lazzaretto, periodic washing of the streets, etc.) actually met the rational constraints which, notwithstanding the reluctances that seem to be inborn in human beings, were abided as well by each state during the current pandemic.

The "run-for-your-life" experience in which every trace of civilization is wiped out, therefore, is not a monopoly of the modern era. Sure, in past times such experiences did not arouse the waves of hyperbolic doubts about the relevance of religious experience that we are used to witnessing today. But, in its revised form, the secularization story precisely boils down to coming to see and absorbing the radically innovative character, both in theory and in practice, of the rise of secularism as a self-contained life-form. In other words, what has changed with the emergence in Europe of the secular option - the condition that was fittingly pictured as an "Immanent Frame" by Charles Taylor - is the routinization of the possibility once reserved only for the elites to see themselves as self-fulfilled people even outside the domain of religious agencies and worldviews. ${ }^{57}$ If, before the modern turn, religions could plausibly claim an exclusive right to symbolically and practically cope with the limit-experiences from which no human being is exempted (birth, entry into adulthood, sexuality, fatherhood/motherhood, aging, bereavement, death), the personal search for a good life has now become a competition of all against all. In the new fractured context, even those who could possibly act as referees (for example, psychologists or celebrities) make use of codes that are systematically contested without exception by all the contenders, who do their best to exploit the new situation with expeditiousness and ingenuity.

Such competition is also a shrewd mirror game. It is not surprising, therefore, that faced with an epidemic that caught almost everyone off guard, someone should maliciously require from religions a sort of mystical self-sufficiency. As I

$56 \quad$ See Snowden, Epidemics and Society.

57 See Joas, Faith as an Option. 
noticed at the outset, however, there is something unfair or at least anachronistic in claiming that they ought not to modulate their behavior by creatively adapting their sense of inherent worth to the skills and knowledge that, in different historical circumstances, enable people to successfully navigate their way through this world. This is not how things operate for people who do their best to maintain a precarious balance between two opposing realities both claiming absolute prominence over themselves. What we have experienced in the unexpected corona health emergency, then, is not a grisly deicidal epidemic. It is rather another interesting chapter of the uncertain story kicked off by modern revolutions, whose most typical feature is dynamism - even spiritual dynamism - and where immunity from risk is not an available option, not just biologically, socially, and psychologically, but even religiously.

\section{Biography}

Paolo Costa studied Philosophy at the University of Milan, where he graduated with a thesis on H. Arendt's and J. Habermas's conceptions of language and public sphere. He did his PhD on Charles Taylor in Philosophical Anthropology at the University of Parma from 1995-1997. In 1997, he was a visiting scholar at the University of Toronto (Department of Political Science) and in 2008, he became a permanent researcher of the Fondazione Bruno Kessler. Paolo Costa's field of expertise is the theory of secularization and post-secular spiritualities.

\section{Bibliography}

Agamben, Giorgio: A che punto siamo? L'epidemia come politica. Perugia: Quodlibet 2020.

Bellah, Robert Nelly: Religion in Human Evolution: From the Paleolithic to the Axial Age. Cambridge, MA: Harvard University Press 2011.

Bilgrami, Akeel (ed.): Beyond the Secular West: Religion, Culture, and Public Life. New York, NY: Columbia University Press 2016.

Blumenberg, Hans: The Legitimacy of the Modern Age (trans. by R. Wallace). Cambridge, MA: MIT Press 1983.

Bremmer, Jan N.: Secularization: Notes Toward a Genealogy. In: Hent de Vries (ed.): Religion: Beyond a Concept. New York, NY: Fordham University Press 2008, pp. 432-437.

Costa, Paolo: La città post-secolare. Il nuovo dibattito sulla secolarizzazione. Brescia: Queriniana 2019. 
Filoramo, Giovanni: Secolarizzazione. In: Piero Coda/Giovanni Filoramo (eds.): Il cristianesimo: grande dizionario. Torino: UTET 2006, vol. II, pp. 693-696.

Jaspers, Karl: The Origin and the Goal of History (trans. by M. Bullock). New Haven, CT: Yale University Press 1953 .

Joas, Hans: Faith as an Option: Possible Futures for Christianity (trans. by A. Skinner). Stanford, CA: Stanford University Press 2014.

Kempel, Gilles: The Revenge of God: The Resurgence of Islam, Christianity and Judaism in the Modern World (trans. by A. Braley). Oxford: Polity Press 1994.

Schutz, Alfred: On Multiple Realities, in: Philosophy and Phenomenological Research (4/1945), pp. 533-576.

Simmel, Georg: Nietzsche and Schopenhauer (trans. by H. Loiskandl/D. Weinstein/ M. Weinstein). Urbana/Chicago, IL: University of Illinois Press 1986.

Sloterdijk, Peter: The Art of Philosophy: Wisdom as Practice (trans. by K. Margolis). New York, NY: Columbia University Press 2012.

Sloterdijk, Peter: You Must Change Your Life: On Anthropotechnics (trans. by W. Hoban). Cambridge: Polity Press 2013.

Sloterdijk, Peter: In the Shadow of Mount Sinai: A Footnote on the Origins and Changing Forms of Total Membership (trans. by W. Hoban). Cambridge: Polity Press 2016.

Sloterdijk, Peter: After God (transl. by I.A. Moore). Cambridge: Polity Press 2020.

Snowden, Frank M.: Epidemics and Society: From the Black Death to the Present. New Haven, CT/London: Yale University Press 2019.

Taylor, Charles: A Secular Age. Cambridge, MA: Harvard University Press 2007.

Taylor, Charles: What Was the Axial Revolution? In:Dilemmas and Connections. Selected Essays. Cambridge, MA: Harvard University Press 2011, pp. 367-379.

Wallace, David Foster: This Is Water. New York, NY: Little, Brown and Company 2009. Wittgenstein, Ludwig: Philosophical Investigations (trans. by G.E.M. Anscombe). Oxford: Blackwell 1963 .

Zabel, Hermann et al.: Säkularisierung, Säkularisation. In: O. Brunner et al. (eds.): Geschichtliche Grundbegriffe. Stuttgart: Klett-Cotta 1984, pp. 789-829.

\section{Internet Sources}

Agamben, Giorgio: A Question (trans. by A. Kotsko), 23.11.2020, https://itself.blog/ 2020/04/15/giorgio-agamben-a-question/ (date of last access: 10.05.2021).

Agamben, Giorgio: Reflections on the Plague (trans. by D.A. Dean), 27.03.2020, https:// d-dean.medium.com/reflections-on-the-plague-giorgio-agamben-b616763b6259 (date of last access: 10.05.2021).

Agamben, Giorgio: Sul tempo che viene, in: Una voce. Rubrica di Giorgio Agamben, 23.11.202O, https://www.quodlibet.it/giorgio-agamben-sul-tempo-che-viene (date of last access: 10.05.2021); trans. by D.A. Dean: Times Ahead (On the Coming Time), 
https://d-dean.medium.com/the-times-ahead-f3991d7cia6f (date of last access: 10.05.2021).

Ansell-Pearson, Keith:Philosophy of the Acrobat: On Peter Sloterdijk. In: The Los Angeles Review of Books, 08.07.2013, https://lareviewofbooks.org/article/philosophy-of-the -acrobat-on-peter-sloterdijk/ (date of last access: 10.05.2021).

Detloff, Dean: Review Essay: Peter Sloterdijk's on Social Bonds, Freedom, and Religion. In: Religious Theory: E-Supplement to the Journal for Cultural and Religious Theory, 10.03.2016, http://jcrt.org/religioustheory/2016/o3/10/review-essay-peter-sloterdijk -on-social-bonds-freedom-and-religion/ (date of last access: 10.05.2021).

Kirsch, Adam: Against Cynicism: A Philosopher's Brilliant Reasons for Living. In: The New Republic, 20.07.2013, https://newrepublic.com/article/113387/peter-sloterdijks -philosophy-gives-reasons-living (date of last access: 10.05.2021).

Lemmens, Pieter: Review Essay. In: ID: International Dialogue. A Multidisciplinary Journal of World Affairs (3/2013), https://repository.ubn.ru.nl/bitstream/handle/ 2066/1506o7/1506o7.pdf (date of last access: 10.05.2021).

Lucci, Antonio: L'animale acrobatico. Origini e sviluppo del concetto di antropotecnica nel pensiero di Peter Sloterdijk. In: Esercizi filosofici (7/2012), pp. 78-97, http:// www2.units.it/eserfilo/art712/lucci712.pdf (date of last access: 10.05.2021).

Mathewes, Charles: Can You Change Your Life? Reflections on Peter Sloterdijk and the Confoundments of Religion in Our Time. In: The Hedgehog Review, 17.03.2015, pp. 34-47, https://hedgehogreview.com/issues/re-enchantment/articles/can-you -change-your-life-reflections-on-peter-sloterdijk-and-the-confoundments-of-reli gion-in-our-ti (date of last access: 10.05.2021).

Mendieta, Eduardo: Review. In: Notre Dame Philosophical Review, 18.07.2014, https://ndpr .nd.edu/news/49344-you-must-change-your-life/ (date of last access: 10.05.2021).

Pope Francis: Urbi et Orbi Blessing. Extraordinary Moment of Prayer Presided by the Pope, 27.03.2020, https://www.vatican.va/content/francesco/en/messages/urbi/ documents/papa-francesco_20200327_urbi-et-orbi-epidemia.html (date of last access: 10.05 .2021$)$.

Ross, Jan (ed.): Religion ist nie cool. In: Die Zeit, 08.02.2007, p. 6 et seq., http://www.zeit .de/2007/o7/Glaube-Interview (date of last access: 10.05.2021).

Testa, Italo: La religione a porte chiuse. In: Le Parole e le Cose, 16.03.2020, http://www .leparoleelecose.it/?p=37948 (date of last access: 10.05.2021). 